\title{
Correction to: FDI in hot labour markets: The implications of the war for talent
}

\author{
Bettina Becker ${ }^{1}$, \\ Nigel Driffield ${ }^{2}$, \\ Sandra Lancheros ${ }^{3}$ and \\ James $\mathrm{H}$. Love ${ }^{3}$ \\ ${ }^{1}$ Aston Business School, Aston University, \\ Birmingham B4 7ET, UK; ${ }^{2}$ Warwick Business \\ School, University of Warwick, Coventry CV4 7AL, \\ UK; ${ }^{3}$ Leeds University Business School, University \\ of Leeds, Leeds LS2 9JT, UK
}

\section{Correspondence:}

N Driffield, Warwick Business School, University of Warwick, Coventry CV4 7AL, UK e-mail: nigel.driffield@wbs.ac.uk
Journal of International Business Policy (2021) 4, 453-454.

https://doi.org/ I 0. I057/s422 I 4-020-00066-6

The online version of this article is available Open Access

\section{CORRECTION TO: JOURNAL OF INTERNATIONAL BUSINESS STUDIES (2020) 3, 107-133 \\ HTTPS://DOI.ORG/10.1057/S42214-020-00052-Y}

The article FDI in hot labour markets: The implications of the war for talent, written by Bettina Becker, Nigel Driffield, Sandra Lancheros and James H. Love, was originally published electronically on the publisher's internet portal on 24 April 2020 without open access. With the authors' decision to opt for Open Choice the copyright of the article changed on 15 July 2020 to (c) The Author(s) 2020 and the article is forthwith distributed under a Creative Commons Attribution 4.0 International License, which permits use, sharing, adaptation, distribution and reproduction in any medium or format, as long as you give appropriate credit to the original author(s) and the source, provide a link to the Creative Commons licence, and indicate if changes were made.

The images or other third party material in this article are included in the article's Creative Commons licence, unless indicated otherwise in a credit line to the material. If material is not included in the article's Creative Commons licence and your intended use is not permitted by statutory regulation or exceeds the permitted use, you will need to obtain permission directly from the copyright holder.

To view a copy of this licence, visit http://creativecommons.org/ licenses/by/4.0/.

\section{OPEN ACCESS}

This article is distributed under the terms of the Creative Commons Attribution 4.0 International License (http://creativecommons.org/ licenses/by/4.0/), which permits unrestricted use, distribution, and reproduction in any medium, provided you give appropriate credit to
The original article can be found online at https://

doi.org/10.1057/s42214-020-00052-y.

Online publication date: 17 August 2020 
the original author(s) and the source, provide a link to the Creative Commons license, and indicate if changes were made. The Creative Commons Public Domain Dedication waiver (http://creativecommons.org/ publicdomain/zero/1.0/) applies to the data made available in this article, unless otherwise stated.

\section{ABOUT THE AUTHORS}

Bettina Becker is a Lecturer in Innovation and Entrepreneurship at Aston Business School, UK. Her research interests lie in the areas of innovation and $\mathrm{R} \& \mathrm{D}$, in particular innovation policy, social and inclusive innovation, entrepreneurship and SMEs, regions, and productivity.

Nigel Driffield is Professor of International Business and Deputy Vice Chancellor at Warwick University. His main research interest concerns the implications of international capital flows for both host and home economies, incorporating labour markets, knowledge flows and firm performance, and policy responses.
Sandra Lancheros is an applied economist with a special focus in the areas of international economics and industrial organization. Her main research interests are the causes and consequences of globalization on firms' performance. She pays particular attention to the activities of multinational companies, including their foreign direct investments, international trade, and their productivity-enhancing investments.

Jim H. Love is Professor of International Business at the University of Leeds. He previously held Chairs in international business and economics at Aston, Birmingham and Warwick Universities. His background is in applied microeconomics. His main research interests lie in the causes and effects of FDI, knowledge transfer within the MNE, and the links between innovation, exporting and productivity. 